\title{
THE JEWS OF LITHUANIA DURING THE MUSCOVITE OCCUPATION (1655-1660)*
}

\author{
Elmantas Meilus
}

ABSTRACT This article deals with the situation of the Jews in 1654 at the beginning of the Muscovite invasion of the Polish-Lithuanian Commonwealth. It is maintained that that was the main reason to the disasters that befell the Jewry of the Grand Duchy of Lithuania. The extant sources (mainly relating to Vilnius) show that in the occupied western lands of the GDL the attitude of the Russian authorities towards the Jews was more relaxed than in the eastern lands inhabited by the Orthodox. Seeking to win the favour of the population of the occupied territory, the Russians tried the Jews and the Christians by the same laws at least in areas where their jurisdiction was introduced. That could mean that Muscovy had no definite programme concerning the Jews at least in the western part of the GDL, inhabited mainly by the Catholics. Meanwhile, the Jews, despite the hostile attitude of the local population - that was attested by the plea of Vilnius authorities to the tsar to evict the Jews from the city - managed to find a way of coexistence both with the locals and the authorities of the occupiers. The sources show that even after the tsar's indication to remove the Jews they continued to reside in the city.

The middle of the seventeenth century is known as one of the most complicated periods in the history of Jewry, especially in Central Europe. According to the accounts of contemporaries and historians, during the Cossack uprising, which started in 1648, the warring parties exterminated one another: the Cossacks - Catholics, and in particular Jews; and the Polish and Lithuanian forces -

* The report on this topic was presented at a conference in Israel; see E. Meilus, The Jews of Lithuania During the Moscow Occupation (1665-1660), Program. The Fourteenth World Congress of Jewish Studies. July 31-August 4, 2005, p. 44; an article prepared on the basis of this report was submitted to the University of Warsaw for publication in 2005; and the present version is supplemented with some new data. 
the Ukrainians. ${ }^{1}$ In this period a part of the Jewish population fleeing from Ukraine and the eastern regions of the GDL, i.e. from the eastern parts of modern Belarus, settled in the western areas of the GDL, in Žemaitija. According to the sources, before the middle of the seventeenth century the Jewish population in Žemaitija was insignificant; meanwhile in the second half of the century their numbers increased greatly. ${ }^{2}$ Prior to 1655 Jews used to settle in more densely Jewish-populated regions of eastern Lithuania and certainly in the capital of the Grand Duchy Vilnius. However in the aftermath of the Muscovite invasion starting in 1654 against the Polish-Lithuanian Commonwealth Jews had to escape from Belarusian cities and towns as a result of the advance of the Russian army into the interior of the GDL. The cause of such behaviour by the Jewish population was not so much the usual fear of war but the old anti-Jewish attitudes of the Muscovite authorities and the actions of the invaders in the occupied Belarusian towns. ${ }^{3}$ Doubtless, the tsar and his milieu having decided идти на недруга своего, на Яна Казимира...и на его владенье на Литовское и Польское Государства войною, ${ }^{4}$ were the principal perpetrators of all disas-

${ }^{1}$ In greater detail, see B.А. Смолій, В.С. Степанков, Украйнска національна револючія XVII cm. (1648-1676 рр.), т. 7 (Kiev, 1999), pp. 99-100, 171-172; concerning the historiography about the contemporary relations between the Jews and the Christians in the Commonwealth, see also A.M. Шпирт, Этноконфессиональные отношения на восточных землях Речи Посполитой в середине XVII в. (еврейско-христианские отношения), abstract of the dissertation for the degree of candidate of history (Moscow, 2009), pp. 4-13, http://www.inslav.ru/images/ stories/other/autoref_shpirt.pdf, last accessed March 2010.

${ }^{2}$ In greater detail, see G. Błaszczyk, Liczebność żydów na Żmudzi w XVIXVIII w., Biuletyn Żydowskiego Instytutu Historycznego w Polsce, 1987(1), cz. 1, pp. 29-30; E. Meilus, 'The small towns of Žemaitija in the seventeenth and eighteenth centuries', Mare Nostrum, 1999/1, ed. Stephen C. Rowell, Vilnius, p. 26. Sh. Stampfer expressed the opinion founded on arguments that in the latter half of the seventeenth sentury in Žemaitija and in other regions of the GDL the Jews settled due to certain new economic possibilities and the density of the population rather than for the sake of security, cf., 'Some Implications of Jewish Population Patterns in Pre-partition Lithuania', Scripta Hierosolymitana, nr. 38, 1998, p. 202; my thanks are due to A. Shpirt for drawing my attention to this article and annotation.

${ }^{3}$ On the tragic fate of the Smolensk Jewry after the capture of the city by Russian forces, see Barbara M. Pendzich, 'Los żydów na Białej i Czarnej Rusi w czasie "Nieznanej wojny" 1654-1667‘, Żydzi i judaizm we współczesnych badaniach polskich, ed. K. Pilarczyk, (Cracow, 1997), pp. 160-161.

${ }^{4}$ Полное собрание законовь Российской империи, т. I, 1649 to 1675 (St Petersburg, 1830) (henceforth - ПСЗРИ), p. 306, nr. 111 (О объявлении войнь Казимиру Королю Польскому и Литовскому). 
ters in these regions. And по прежния и нынешния неправды ${ }^{5}$ of the other side and further decrees of that 'most gracious' sovereign concerning the most lenient treatment of his new defeated subjects can disclaim his historical and humane responsibility. Therefore it is impossible agree with Barbara M. Pendzich's remarks that historians usually lay the blame for committed crimes on Bogdan Chmielnicki keeping Tsar Alexei Mikhailovich aloof, although it was he who organized the military campaign after $1654 .^{6}$

In the early stages of the war Muscovy and its ally Chmielnicki very clearly expressed their attitude towards Jews and Catholics in the occupied territories: костелам не быть... униатам не быть... жидамь вь Белоруссии не быть и жития никакого не имети. ${ }^{7}$ At the beginning of the war Alexei Mikhailovich himself personally instructed his palatines: Будеть Белорусиь, а будеть Ляхи будут в городехъ, а не похотять креститияа, и ихъ сечь и Белорусиовъ сечь. ${ }^{8}$ And although in the last case the Jews were not referred to by name, as the fate of the Christians was obvious, the destiny of the Jews was clear without any additional clarification. True, some historians take the view that despite war losses Muscovy was quite tolerant of the Jews at that time or for instance they doubt the correctness of the traditional view that in that period the Jews of that region suffered a deep economic, demographic, social and cultural crisis. ${ }^{9}$

Therefore, as the Russian army approached the borders of Lithuania, Jews and other inhabitants fled westward into the interior of the country. According to Aleksandr Mal'tsev, the Catholic priest Rafol, having come to the headquarters of the Russian army at the

${ }^{5}$ ПСЗРИ, р. 293, nr. 104 (Постановление собора, бывшаго въ присутствии Государя Царя Алексея Михайловича изъ духовныхъ и светскихъ чиновъ, касательно объявления войны Польскому Королю...).

${ }^{6}$ Pendzich, 'Los żydów', p. 158 (Można sobie wyobrazić, że na Chmielnickiego spadto cale odium, a przecież to car stat na czele potężnej sity politycznej popieranej przez hierarchie kościelnq $i$ to car organizowat kompanię wojenna ).

${ }^{7}$ Г. Сагановіч, Невядомая вайна 1654-1667 (Minsк, 1995), p. 28; on the fate of the Jews and other burghers of Belarusian towns, see also pp. 17-32; Pendzich, 'Los żydów', p. 158.

8 Записки отделения Русской и славянской археологии Императорскаго русскаго археологическаго общества, t. II (St Petersburg, 1861), p. 715.

${ }^{9}$ Ю. Гессенъ, История евреевъ въ России (St Petersburg, 1914), pp. 11-13; on the destiny of the Jews of Pinsk at that time, see M. Nadav, 'Kehilat Pinsk b'tkufa she'm'gzeirot TaH-TaT ad shlom Andrushow', Pinkas Patuach. Mechkarim betoldot yehudi Polin ve'Lita (Tel-Aviv, 2003), pp. 29-72 (I am grateful to A. Shpirt for drawing my attention to this excellent article and its annotation). 
approaches to Vilnius, reported having heard the bishop of Vilnius allegedly saying that будто бы богатые мещане и евреи со своим имуществом из Вильно выехали в Польшу. ${ }^{10}$ But as a matter of fact the situation was not so critical. It was known that since the beginning of the war the city and the forces of the GDL had been preparing for the defence, and the Jews of the city were also taking part in these preparations. That process was vividly described in the memoirs of the physician of King Władisław Vasa: До того дошло (о чем раньше никогда не было слышно), что и евреи со своим собственным знаменем (было красное, по краям листья белые, с обеих сторон гебрайские надписи) выставили 130 имеющих желание воевать и хорошо экипированных евреев. ${ }^{11}$ But that was a novelty only for the author of the memoirs, since at that time the Jews had been known fighting together with the burghers in the besieged cities of Staryi Bykhov, Vitebsk and other Belarusian towns. ${ }^{12}$ It is not clear whether the Jews participated in a short-term defence of Vilnius a year later; however, according to Vorbek-Lettow, they had previously conducted reconnaissance. ${ }^{13}$

At all events, the capital of the GDL was captured by the Muscovite forces. Contemporaries and historians state that Vilnius was plundered and burnt, and thousands of its inhabitants were either killed or fled. On the basis of contemporary reminiscences about the capture of Vilnius, nineteenth-century scholarship and imperial points of view, Professor Vasilii Vasilevskii maintains: Война вообще велась со всеми ужасами войнъ столетия, со всеми кровавыми признаками национальной мести и религиознаго ожесточения. Паны, Поляки и Жиды осуждены были заранъе на безпощадную

10 А.Н. Мальцев, Россия и Белоруссия в середине XVII века (Moscow, 1974), p. 92.

${ }^{11}$ Maciej Vorbek-Lettow, Skarbnica pamięci. Pamiętnik lekarza króla Władysława $I V$, ed. E. Galos and F. Mincer (Wrocław-Warsaw-Cracow, 1968), p. 184.

${ }^{12}$ Сагановіч, Невядомая вайна, pp. 25, 26; M. Horn, Powinnośc wojenne Żydów w Rzeczypospolitej w XVI i XVII wieku (Warsaw, 1978), pp. 104-115; К. Бабятински, 'Стары і Новы Быхау у час вайны Речи Паспалітай з Масквой (1654-1655)', Беларускі Гістарычны Агляд, т. 10, 2003, pp. 95, 113, 118; idem, Od Smoleńska do Wilna. Wojna Rzeczypospolitej z Moskwa 1654-1655 (Zabrze, 2004), p. 129; an interesting account of how in 1655 г. in Staryi Bykhov осадные люди, иляхта, и немщь, и жиды и мещане межъ себя присягали... is found in Акты Московскаго государства, изданные Императорскою академиею наукъ, ed. Н.А. Попов, т. ІІ: Разрядный приказъ. Московский столъ. 1635-1659 (St Petersburg, 1894) (henceforth - $A M \Gamma$, т. II), p. 448, nr. 734.

${ }^{13}$ Vorbek-Lettow, Skarbnica pamięci, p. 184. 
гибель тамь, где являлся Золотаренко со своими удальцами. Furthermore he speaks about the spontaneous resistance of the townsmen that broke out on the city's market square. That conflict irritated the conquerors yet more and incited their hatred, doubtless leading to the injuries of other inhabitants. ${ }^{14}$

The extent of the destruction has not been assessed properly yet. However, it is clear that the total number of casualties put at 25,000 in the memoirs of the contemporaries is an exaggeration (nearly all historians doubt the truth of that number). Formerly the estimates of Józef Morzy were considered more reliable: during the six years of the occupation of the total number of about 40,000 inhabitants Vilnius lost 20,000 including those who died following a major outbreak of plague. ${ }^{15}$ However, from a recently published list of Vilnius houses ${ }^{16}$ we see that the total population of the city did not exceed 20,000 persons before the beginning of the occupation. ${ }^{17}$ It is still more difficult to determine the size of the Jewish community in Vilnius. According to Maria Łowmiańska, ten years before the occupation (in 1645) 272 families lived in the houses appointed for Jews in only three streets; if each family consisted of five members, the total number would be about 1,360 persons. ${ }^{18}$ During ten years that number could grow to at least 1,500 or 2,000 and even more (not taking into account the Jews living in the outskirts). After the liberation of the capital, in 1662, the numbers of the Jews vary

14 В.Г. Васильевский, 'Вильна подь Русскою властью (1655-1661)', Памятники Русской старины въ Западныхъ губернияхъ империи издаваемье по Высочайшему повелению П.Н. Батюшковымъ, выпускъ 6, (St Petersburg, 1874), pp. 51-52.

15 J. Morzy, Kryzys demograficzny na Litwie i Białorusi w II połowie XVII wieku (Poznań, 1965), pp. 193-196; similar numbers are presented by Alfonsas Tamulynas, 'Vilniaus gyventojų skaičiaus XVII a. viduryje klausimu', Jaunuju istoriku darbai, kn. 6 (Vilnius, 1987), pp. 113-116.

${ }^{16}$ M. Paknys, Vilniaus miestas ir miestiečiai 1636 m.: namai, gyventojai, Svečiai (Vilnius, 2006).

${ }^{17}$ Ibid, p. 18; also E. Meilus' review of Paknys book, Lietuvos istorijos metraštis (2008, Vilnius), pp. 111-116; Wilnianie. Żywoty siedemnastowieczne, edited, introduced and commented on by David Frick, Studium Europy Wschodniej, Bibliotheca Europae Orientalis, t. XXXII, fontes 2 (Warsaw, 2008), p. xx.

${ }^{18}$ M. Łowmiańska, Wilno przed najazdem moskiewskim 1655 roku (Vilnius, 1929), p. 76; It seems that there are similar new data, cf. D. Frick, 'Jews and Others in Seventeenth-Century Wilno: Life in the Neighborhood', Jewish Studies Quarterly, vol. 12 (2005), no. 1, p. 13. 
between 415 and 830 (it must also be taken into consideration that since the second half of 1660 a number of Jews may have returned from forced emigration). ${ }^{19}$ Thus, as was noted by Lowmiańska, ${ }^{20}$ the Jewish population decreased markedly more than the Christian community - between 50 and 75 per cent (that does not mean that all of them perished).

As has been noticed the Russian historians of the nineteenth century Sergei Solov'ev, Vasilii Vasilevskii and Vasilii Storozhev noted that the tsar ordered his army to treat the inhabitants of the occupied regions kindly in order to win them over. ${ }^{21}$ A closer acquaintance with narrative sources and others too makes one agree with Vincas Trumpa's statement that 'they also have positive data for asserting that the citirentry came to terms with the occupying forces quite quickly'. ${ }^{22}$ Nevertheless, the first days after the capture of Vilnius were the most complicated since the conquerors, and in particular the Cossacks of Hetman Zolotorenka, wanted to have their reward for the hardships of the war and started plundering everything without distinction. A number of authors witnessed the scale of marauding and the pillage taken to Moscow. Among them was the envoy of Venice Michele Bianchi who watched thousands of wagons carrying through Smolensk the booty seized in Vilnius and in other towns of the GDL as well as thousands of men, women and children taken into servitude. ${ }^{23}$ The scale of the desolation of Vilnius can be seen from the list presented to the tsar in $1658 .{ }^{24}$

${ }^{19}$ J.I. Kraszewski, Wilno od poczatków jego do roku 1750, t. III (Vilnius, 1841), p. 193; Tamulynas , 'Vilniaus gyventojų ...', p. 115.

${ }^{20}$ Łowmiańska, Wilno, p. 76.

${ }^{21}$ С.М. Соловьев, История России с древнейших времен, кн. V, т. X (Mocow, 1961), p. 642; Васильевский, 'Вильна', pp. 54, 57; the decrees proper, see ПСЗРИ, pp. 369-370, nr. 165, p. 370, nr. 166, p. 390, nr. 181; В.Н. Сторожев, 'Московское управление в Вильне XVII века', Труды девятаго археологическаго сьезда в Вильне 1893, т. I (Moscow, 1895), pp. 133-134.

${ }^{22}$ V. Trumpa, 'Pirmą kartą rusams okupavus Vilnių 1655 m.', Lietuvos aidas, 26 Oct. 1939 , nr. 646, p. 5.

${ }^{23}$ Michele Bianchi (Alberto Vimina), Trumpas pasakojimas apie Lietuvos ir Lenkijos karq su Maskva XVII a. viduryje. Breve racconto della guerra di Lituania e Polonia contro Mosca alla meta del XVII secolo, ed. V. Dolinskas (Vilnius, 2004), pp. 114-143.

24 Российская Государственная Библиотека (Moccow), Отдел рукописей, ф. 178 (Музейное собрание), оп. 4, картон nr. 6916, Материаль Виленской сьезжей избы за 1655-1659 г2. (henceforth - ОР РГБ, ф. 178, оп. 4, nr. 6916) (д. 187); a copy of this inventory in Latin characters is to be found in the Manuscript Department of the Russian National Library, St Petersburg, ф. 550 (Основное 
Of the total number of 1,300 commercial places in the city in 1647 only 40 were found eleven years later, in $1658 .{ }^{25}$

Nevertheless, before the fall of the capital many Vilnius denizens, in particular the rich ones, including a lot of Jews, fled to Žemaitija, Prussia, Kèdainiai and other cities and towns. ${ }^{26}$ Usually valuables that could not be taken or for fear of being lost were buried, immured in cellars or kept in monasteries and churches. So did the Jews. Thus the Vilnius Jew Levka Maerovich complained that after his return to the capital he could not find various things - clothes, valuables, crockery and much other property he had hidden in the cellar. Detailed descriptions of lost property give a glimpse into the contemporary daily life of Vilnius Jews. ${ }^{27}$

собрание рукописной книги), д. F.II.85 (henceforth - ОР РНБ, ф. 550, д. F.II.85), pp. 43-46. This inventory is also kept in the Lithuanian State Historical Archive (Vilnius) (henceforth - LVIA), f. 458, ap. 1, b. 14.

${ }^{25}$ LVIA, f. 458 , ap. 1, b. 15, fos. 6-7; see also Łowmiańska, Wilno, pp. 156-159; on the damage done to the city and the situation of its economy in 1657 , see also J. Obst, 'Rachunki miasta Wilna', Litwa i Ruś, 1913, rok ii, zeszyt vii-xix, ed. J. Obst, Vilnius, pp. 81, 102-104.

${ }^{26}$ One such Vilnius Jew by the name of Wolf is mentioned in the king's universal early in 1657 as having left the city during the turmoil in the country with various things and valuables pawned to him, cf. Metryka Litewska. Księga wpisów Nr 131, ed. A. Rachuba (Warsaw, 2001), p. 52, nr 132. And 14 years later in his privilege for the Jews of Vilnius king Michał Wiśniowiecki recalls: $a$ żydzi po różnych mieysach y miastach tułać się musieli..., cf. Aкты, издаваемые Виленскою коммиссиею для разбора древнихъ актовъ, т. ххіх, Акты о евреяхъ, (Vilnius, 1902), p. 27.

${ }^{27}$ Российский государственный архив древних актов (henceforth - РГАДА), ф. 1603 , оп. 12 , е.х. 14 , pp. $518-519$, the statement of a Jew on dug-out property (23 July1660): Protest Lewka Maierowicza zyda o wykopanie rzeczy. Przed sad y szlachetny urzad burmistrowski y radziecki Wilenski przyszedszy oczewiscie niewierny Lewek Maierowicz, zyd Wilenski cum solenni protestave' denunciowat temuz sqdowi y urzędowy ze onemu w roku ninieyszym we srzodę blisko przeszła to iest dnia 21 july rzeczy niemato takiego wtasnych iako y od roznych osob $w$ zastawe danych, $w$ mieszkaniu iego $w$ piwnicy $w$ ziemi schowanych, $z$ baniq $y$ czapka do niey nalezqca, $w$ ktorey te rzeczy $y w$ drugiey kadce złozone y wkopane byty ktore ile moze na ten czas maie w pamięci tak specifikuie // naprzod chusty białe rozne tak samego pomienionego Maierowicza matzonki onego iako y dziecinne, deliq falendyszu przedniego fiiołkowego z lisztwa kitayczana, deliyke falendyszowa wiszniowq kitayka podszyta, dołoman falendyszu łazurowego, pare sobola, sznurek perel, kubeczek pozłocisty srebrny, srebro od kielicha, kuntusz łazurowy lundyszowy, sukienkę tureckiego muchaieru, puł czamarek takze tureckiego muchaieru brzuszkami popieliczemi podszyty, czamare Ryskiego muchaieru, garniec nowy miedziany dwa trzynozki, trzewykow nowych niemieckich dwie pary, tyszki dwie srebr', tales muchaieru białego zydowski y kitell cyny sztuk szesc, cztyry misy duze, a dwa putmiski, y innych niemało ktorych niemoze przypomniec, wykopano y wykradziono; in greater detail about the then hidden treasures, see E. Meilus, "Apie rastą lobi, paslèptą 
Historians generally consider that Muscovy's attitude to the Jews was always rigid, both in old and newly occupied regions. Mal'tsev noted that характерно разделение занятой русскими войсками территории на две части - до р. Березины и «за Березынею от Белоруссии». Первую часть русское правительство безоговорочно рассматривало подлежащей русским порядкам, во второй - по тактическим соображениям допускались отступления. Но и та, и другая половины занятой территории считались навеки присоединенными к России. ${ }^{28}$ According to Lev Zaborovskii, the Muscovite administration initially intended to ban Catholic churches even in Vilnius, Trakai and Grodno, let alone the occupied lands of the GDL on the left bank of the Berezina, although their functioning was allowed on the whole right-bank territory. However, when the representatives of Oshmena gentry expressed their protest, the tsar condescended and указал духовенству римские веры быть по реку Березу, а в Вилно униятикие иеркви все да половину костелов римских обратить в греческие иеркви. Также и в замку костелу не быть, а быть тут соборной греческой иеркви... ${ }^{29}$

The question naturally arises about how the Muscovite administration behaved towards the Jews in the newly occupied territories. The facts of the exile of Jews together of other inhabitants of the GDL to the interior of Muscovy were reported in a number of sources. Thus, in Актах Московского государства Отписке Нижегородскаго воеводы Ив. Бутурлина объ отправке жидовъ и литвы въ Казань, кроме жида Хамина, изявивмаго желание креститься..., published in the summer of 1655 it was stated that ...жидовъ съ женами, и съ детьми, и съ племянниками, и съ челядью, и колодниковъ литовскихъ людей...brought to Nizhnii Novgorod on the prescript of the tsar it was necessary to send further to Kazan. ${ }^{30}$ There are data indicating that several Jews, former prisoners, were living in Moscow, but Въ сущности, пребывание этихъ

žemėje ar kitoje vietoje, arba 1655-1661 m. Vilniuje paslėptų lobių ieškotojo pradžiamokslis', Istorijos akiračiai, ed. E. Rimša (Vilnius, 2004), p. 253.

${ }_{28}^{28}$ Мальцев, Россия, р. 161.

29 Л.В. Заборовский, Великое княжество Литовское и Россия во время польского Потопа (1655-1656 гг.). Документы, исследование (Moscow, 1994), pp. $85,89,92,93$.

${ }^{30} A M \Gamma$, т. II, pp. $428-429$, nr. 701 ; the appearance of Jews along the Volga is attested by the decree of 7(17) March 1655 - О высылке изъ Калуги въ Нижний Новгородъ Литовиевъ и Жидовъ, ПСЗРИ, р. 359, nr. 148. 
евреевъ въ Москве было противозаконно, такъ какъ вообще иноземиь, взятые въ пленъ, ссылались въ более отдаленные края. ${ }^{31}$ Zaborovskii presents information from the contracts of 26 November (6 December) 1655 between the tsarist authorities and the gentry of three Lithuanian powiats (districts) of which the last seventeenth - article says: Также татаровя и жиды чтоб против прав старожитных давных были попрежнему. ${ }^{32}$ Regrettably, this article (as well as many others) lacks commentaries of tsarist institutions in Moscow. However, prince Semen Urusov, the coordinator of these articles, wrote: $А$ мещуаном и приезжим людем $к$ домовствам своим, и татаром, и жидом царскому величеству дани, и оброки, и всякие подати платить так давать, как они плотили полскому королю. ${ }^{33}$ Thus, tsarist authorities, for the sake of profit and calm, somehow agreed with the proposals of the Lithuanian gentry, which in the eyes of the Muscovite government always seemed a protector of Jews. ${ }^{34}$

In occupied Vilnius Palatine Prince Mikhail Semionovich Shakhovskoi was appointed head of the Muscovite occupation administration. In October 1655 he received Государеву грамоту ... п призыве иляхты, мещчань и пашечныхъ крестьянь на ихъ прежния жилищи, demanding to swear an oath of allegiance to the tsar. The letter, however, made no mention of the Jews, who could not be treated as мемань according to the legislation of the GDL or in the interpretation of the Muscovite government. ${ }^{35}$ Neither were they mentioned in an analogous letter sent from Minsk. ${ }^{36}$ Shakhovskoi's answer to the tsar about administering the oath in December also

${ }^{31}$ Гессенъ, История евреевъ, р. 12 (the author of the book does not indicated the source of the 1659 document).

32 Заборовский, Великое княжество, p. 106; see also, idem, Католики, православные, униаты. Проблемы религии в русско-польско-украинских отношениях кониа 40-x - 80-х г2. ХVII в. Документы. Исследования. Часть 1: Источники времени гетманства Б.М. Хмельниикого (Moscow, 1998), p. 247.

${ }^{33}$ Ibid.

${ }^{34}$ In her article 'Паміж раем і клаакай, або як мог бачыць свае месца у грамадстве мещанін ВКЛ XVII ст.' (Беларускі Гістарычны Агляд, т. 5, (Minsk, 1998), p. 410), Pendzich without indicating the source mentioned an unknown author who in 1663 wrote to the tsar Aleksei Mikhailovich referring to the Commonwealth as a stinking cesspool in which all nations of the world found shelter and intermingled; while a Jew from Amsterdam in 1655 held the Commonwealth as an example to Oliver Cromwell.

${ }^{35} A M \Gamma$, т. II, pp. 444-445, nr. 727.

${ }^{36} A M \Gamma$, т. II, p. 456, nr. 747. 
did not contain any reference to the Jews. ${ }^{37}$ However, as was noted by Storozhev in his so far unsurpassed article about the Muscovite administration in Vilnius in the seventeenth century ... не смотря на резко выраженное желание московскаго правительства привлечь разошедшееся въ разныя стороны население на прежния места жительства, князь М.С. Шаховской не решился безъ государева указа поселить на старыхъ местахъ въ Вильне евреевъ. ${ }^{38}$ In his answer the Muscovite palatine remarked that on 28 December 1655 there сате къ твоей государской милости въ Вильну жидовъ 2 человека, и били челомъ тебе, великому государю, чтобъ имъ жить въ старыхъ своихъ домехъ; а сказали мне, что будеть ихъ

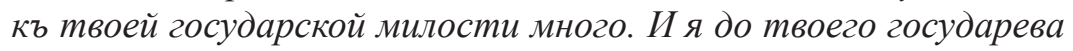
указу, темъ жидомъ въ Вильне велель жить на посаде; а впредь которые жиды учнуть приходить къ твоей государской милости въ Вильну, и мне ихъ принимать-ли, или нетъ, и въ прежнихъ ихъ домехъ жить велеть-ли? И о томь мне какъ ты, государь, укажешь. ${ }^{39}$ Now it is difficult to say whether the palatine kept his promise not to let the Jews to live in the city and what was the tsar's directive in this case. Later, at the beginning of 1657, the Jews were seen within the boundaries of the city. Nevertheless, the sovereign must have issued his указ on taking oaths of allegiance by the Jews since there exists a list of 43 Vilnius Jews dated the beginning of 1656, let alone the Jews of other towns who had taken oaths of loyalty to the tsar. ${ }^{40}$ On his return to Moscow in 1660 a list of Shakhovskoi's services to the tsar in Vilnius was made. It contains a mention of probably the same Jews who had taken oaths of loyalty to the tsar: Февраля съ 20 ч., июня по 10 ч. [1656 г.] учинились подъ государевою высокою рукою и къ вере приведены Виленского и иныхъ поветовъ литовскихъ начальныхъ людей и иляхты и благочестивые веры чернцовъ и литовскихъ ксенжь и мещанъ и поветныхъ людей и жидовъ 1968 ч.;... ${ }^{41}$

${ }^{37} A M \Gamma$, т. II, p. 458, nr. 751.

38 Сторожев, 'Московские управление', р. 134.

${ }^{39} A M \Gamma$, т. II, p. 483, nr. 794.

${ }^{40}$ РГАДА, ф.145, оп. 1, д. 3, fos. 467-469, Кн(и)ги виленские кр(Б)стоприводные шляхте, и мещаном, и повьтным людем, и иноком, и ксенжам, $и$ жидом, которые учинилис под Г(о)с(у)даревою высокою рукою февраля зъ 20 числа июня по десятое число при воиводе при кн(я)зь Михаиле Семеновиче Шаховскомъ (my thanks are due to Irina Gerasimova for drawing my attention to this document and its copy).

${ }^{41}$ АМГ, т. III: Разрядный приказъ. Московский столъ, 1660-1664 (St Petersburg, 1901) (henceforth - $A M \Gamma$, т. III), p. 40. 
Permission for Jews to live in the occupied towns of the GDL is attested by Государева грамота Гродненскому воеводе..., which in July 1656 indicated: A которые жидь придуть вь Гродно и учнуть намъ, великому государю, бить челомъ,чтобъ имъ быть подь нашею царскаго величества высокою рукою; и ты бъ техъ жидовъ принималь и къ вере по ихъ закону приводиль, и велел имъ жить въ Гродне по прежнему, да о томъ къ намь писаль. ${ }^{42}$ In this last case the requirement къ вере по ихъ закону приводиль is noteworthy since it shows that the oath of allegiance to the tsar by the Jews had to be taken in accordance with Jewish customs and conversion to Orthodoxy was not required.

Some sources indicate that the Jews had this chance later as well. For example, in March 1659 the Lida Jew Mundugai Tomashev came to Vilnius to swear an oath and reported about the handover of Grodno by the Russians to the Lithuanian forces. ${ }^{43}$

Well known and widely described are the pleas of Vilnius burghers to the tsar in April 1658 among other things containing requests to remove the Jews outside the boundaries of the city. They were accused of competing with Christian artisans and traders of the city, of spreading various diseases and buying stolen things (the same blame was put up on the Scots and English). ${ }^{4}$ In this respect the deliberations of Vasilevskii are of interest, too: Виленское гражданство хорошо знало, что Жиды не пользовались такимь расположениемь въ Москве, какое находили они у польскаго правительства, и очевидно на это расчитывало. Еще въ 1654 году, по просьбе Могилевскихъ гражданъ, иарь Алексей Михайловичь велель всехь Могилевскихь Евреевь выслать вонь изъ Могилева. Съ просьбой подобнаго рода обращалась къ нему теперь и христианская Вильна. Такь какъ Жиды наносять большой ущербъ христианскимъ купцамъ и ремесленникамъ, кроме того, распространяють въ городе всякую заразу и болезни по своей нечистоте и неопрятности и, что всего хуже, принимають разныхъ подозрительныхъ людей и всякия краденыя вещчи, не исключая ичерковныхъ и костельныхъ, то магистрать ходатайствоваль чрезь своихь депутатовь объ удалении Жидовъ изъ города, съ разрешениемь жить имъ за стенами,

${ }^{42} A M \Gamma$, т. II, p. 520, nr. 858.

${ }^{43}$ ОР РГБ, ф. 178, оп. 4, nr. 6916(д. 58); ОР РНБ, ф. 550, д. F.II.85, fos. $32-$ $32 \mathrm{v}$; the same in РГАДА, ф. 79, оп.1, 1659 г., д. 1, fos. 90-91.

${ }^{44}$ Kraszewski, Wilno, т. II, p. 125; see also Wizerunki i roztrzasania naukowe, Poczet nowy drugi, т. 17, (Vilnius, 1840), pp. 119-139. 
где находилось еврейское кладбище. ${ }^{45}$ Incidentally, at that time the Jewish cemetery was exactly opposite the castle of Vilnius on the other bank of the Neris in the Fishermen's suburb. ${ }^{46}$ According to Frick, Vilnius Jews, unlike those of Cracow and Warsaw, lived in a specially appointed quarter within the city walls, actually in the centre of the city. ${ }^{47}$ This circumstance could not but incur the displeasure of the burghers. Therefore they decided to solve their problems with the help of the Muscovite government.

At that time the tsar still adhered to his former policy to win the favour of the majority of the population in the occupied territories with kindness. Consequently, in July 1658 he confirmed the old privileges and allowed (maybe because the Jews were in the minority) а Жидовъ изь Вильны выслать на житье за городъ, а приезжих мещань въ те городы, где кто живаль на передь сего. ${ }^{48}$ Incidentally, already in the early 1657 the tsar instructed the palatine of Vilnius Shakhoskoi those who did not swear allegiance to the tsar [...] Польскихь и Литовскихь людей...вь городь не пущали, чтобь оть того в Вильне какое дурно не учинилось [...] а сей Нашь указь держаль еси у себя тайно, чтобь никто опричь тебя вь Вильне про то не ведаль. ${ }^{49}$ Thus the actions of the Muscovite government depended on the situation.

The fact that the Jews lived in Vilnius within its walls at least from 158 and until its liberation in 1660 is attested by the books of revenues and expenses. They show that жидовка вдова Маркова и жидовка Израелова ${ }^{50}$ paid for water supply to their houses between 1658 and 1661. In his work Виленския приходныя каменишныя книги 1658 года Storozhev noted that среди арендаторовъ дворовъ видимъ... четырехъ евреевъ (...одкупь жиду Давыљку Копылову.., жиду Марку.., жиду Илюшке Гронову.., жиду Марчьку Яковлеву). ${ }^{51}$ True, rental does not mean residing there,

${ }^{45}$ Васильевский, 'Вильна', р. 62.

${ }^{46}$ Kraszewski, Wilno, т. III, p. 172; in greater detail, see E. Meilus, 'The History of Vilnius Old Jewish Cemetery at Snipiškès in the Period of the Grand Duchy of Lithuania', Lithuanian Historical Studies, vol. 12, 2007 (Vilnius, 2009), pp. 63-92.

\footnotetext{
${ }^{47}$ Frick, 'Jews', p. 13; see also Obst, Rachunki, pp. 92-95, 100-101.

${ }^{48}$ ПСЗРИ, p. 459, nr. 232.

49 ПСЗРИ, p. 414, nr. 198.

${ }^{50}$ LVIA, f. 458 , ap. 1, b. 15, fos. 8, 15, 15v; and b. 17, fos. 4v, 5, 15v, 16.

${ }^{51}$ Сторожев В.Н., Виленскія приходныя каменишныя книги 1658 года, Труды девятаго археологическаго съезда въ Вильне 1893, т. I (Moscow, 1895), pp. 144, 145, 146, 150,151; by the way, the list of the Jews sworn in 1656 com-
} 
nevertheless it indicates a sort of economic activity pertaining to the Jews within the town walls.

Contemporary published $(A M \Gamma)$ and unpublished sources in the Russian State Library and Russian National Library bear witness that the Jews of big and small towns informed the Muscovite administration in Vilnius. However such informers could also be found among the gentry, Catholic priests, and common people of various faiths; sometimes they cooperated with the Jews. ${ }^{52}$ For example, there is an interesting fact of such collaboration: on 24 January (2 February New Style) 1659 two inhabitants of Vilnius - Mikhailo Stepanov and Abram Khodarkovskii - in their account to the Muscovite palatine in Vilnius report that being in Kedainiai on business they learned what was happening in Kaunas and in other places. ${ }^{53}$

The Jews used to come with their goods to Vilnius from various places in Lithuania and consequently like any other travellers they were questioned by occupation authorities about what they saw and heard on their way as, for instance Aron Isakov from Švenčionys (Svincan) early in 1659. ${ }^{54}$

Some of the extant documents of the so-called Виленская съезжая изба (the court of the Muscovite palatine) show that the Jews often applied to the court of the occupation administration and were given positive judgements. Thus, in April 1657 two Rozhansk Jews claimed that in Vilnius in Jewish Street they had two horses stolen and they caught the thief from a nearby village, but afterwards they made peace with him and all were discharged. ${ }^{55}$ Then, this time a peasant from the Ašmena powiat took to court the Vilnius Jew Isak Levkov accusing him of the theft of an ox; the Jew however proved that he had bought the ox and he was released. ${ }^{56}$ In April

prises only David Kopelevich, Zelman Iakovlev and two more Jews by the name of Mark, see РГАДА, ф.145, оп. 1, д. 3, fos. 467-469.

${ }^{52}$ There is a specific account of the palatine of Vilnius Shakhovskoi registering such cases in 1656, see $A M \Gamma$, т. II, pp. 521-522, nr. 859. Meanwhile Vasilevskii states, on the basis of one letter, that the Jews cooperated allegedly only with the representatives of the Commonwealth: Въ конце октебря того же (1660) года, Жиды, служивщие шпионами у Поляков, распространили на Литве слухи, что Русские сбираются выручить Вильну.., see idem, 'Вильна', р. 71.

53 ОР РГБ, ф. 178, оп. 4, nr. 6916(д. 56); ОР РНБ, ф. 550, д. F.II.85, pp. $37-37 \mathrm{v}$.

54 ОР РНБ, ф. 550, д. F.II.85, pp. 41v-42.

55 ОР РГБ, ф. 178, оп. 4, nr. 6916(д. 155); ОР РНБ, ф. 550, д. F.II.85, pp. $100,101 \mathrm{v}-102$.

${ }^{56}$ ОР РГБ, ф. 178, оп. 4, nr. 6916(д. 157); ОР РНБ, ф. 550, д. F.II.85, pp. $98 \mathrm{v}-99 \mathrm{v}$. 
1657 the Vilnius Jewish woman Sheina, Moisei's wife, took the Russian soldier Mishka Isakov to court for beating her. The soldier excused himself by saying that the woman severely scolded him. The decision of the palatine's court was Мишка бить ботоги за то (for) неуправливался собою..., and then he was released. ${ }^{57}$

On 21 April (5 May New style) an interesting case was recorded, in a way illustrating the plea of Vilnius burghers to the tsar relating to the Jews. A peasant of Vilnius powiat Avgustinka Narkeev was caught with a box containing valuable things and money. During interrogation he stated that тот де сундучок... отнял у жида в Вильне на Жидовской улице... на утреной заре и ночевал де он Августинка тое ночи в шпитале, шол на рынок спрашивать работы, а тот де жид с тем сундучком попал я на встречу и знал де что у него жида краденое, потому что несет да оглядывается и он де Августинка у того жида сундучок отнял... и тот жид и утек неведомо куды... а назвал де он Августинка тот сундучок и стакан своим а некраденымъ. The judge told the peasant to find that Jew from whom he took away the box, and the things in it were given to the Vilnius Jewish woman who identified them. Finally Августинка того жида не сискал и апрела в 26 ден вдова жидовка Тадаска Езуфова била челом Государю словесно чтоб того крестьянина... бив ботоги и с судные избы освободит. И тот крестьянин... бит ботоги и с судныя избы освобожен. In this case one more circumstance is of interest, that is, that the Jews were very well acquainted with the laws and knew how to use them. The Jewish owner at first identified only a part of the things stolen by Avgustinka and then applied to the Russian palatine since тот Государь войт прихожихъ людей и приежжсих судить неповинен; she insisted on that thief being brought before the Muscovite palatine and that was done. ${ }^{58}$

Attempts to reconcile during the court hearing can also be found. In March 1657 a servant and two peasants of an officer were arrested drunk at Vilnius market at the request of two Jews from Novogrudok powiat. During the confrontation the three confessed that they had robbed the Jews of pepper and bread on their return from Vilnius. All of them were found guilty and за их воровство

57 ОР РГБ, ф. 178, оп. 4, nr. 6916(д. 160); ОР РНБ, ф. 550, д. F.II.85, p. $132 \mathrm{v}$.

58 ОР РГБ, ф. 178, оп. 4, nr. 6916(д. 162); ОР РНБ, ф. 550, д. F.II.85, pp. $152-152 \mathrm{v}, 133-135 \mathrm{v}$. 
вместо кнута бить в ботоги.... However, the most interesting thing was that before administering justice the aggrieved party submitted an application declaring that theу в том деле не дожидаючись по роспросу вершения про меж собою помирились. Nevertheless, their request was rejected and the judge punished the robbers. The application of the Jews showed the sort of their trade: грабежем $y$ нас сирот взяли товару дватиат фунтов периу, да пол фунта гвоздики, да два фунты оливы, да дватиат пять кукол хлебов ситних, да четверть бочки овса, да полтора фунта фиги, да четыре фунта кмину, да десяти брусков мыла, да два фунта имбирю, да телегу товарную, да одинатиать коп деньгами. ${ }^{59}$ In another lawsuit of about the same time the Vilnius townsman Petrushka Aleksandrovich put the blame on the peasant Krsiuk Vasil'evich for stealing his cow. The latter confessed that he had stolen the townsman's cow at the request of the Vilnius Jew Abramka Izrail living in Jewish Street and had given it to his client but had not yet received any money. The Jew denied the charge. During the confrontation the peasant again confirmed his evidence, and there are no data about what Abram Izrail said. However subsequently all three of them wrote a petition presenting the case and unexpectedly declaring: и я сирота Петрушка тому Крисюку да жиду Абраму в том покраже в корове не истиа, а Тебе великому Государю не на нихъ челобитчикъ и въ предъ на нихъ того дела неспрашивал. The court made the following ruling: И апреля в 8 ден противъ сей мировой челобитной Вилинского повету села Жураны крестьянин Крисючка Васильевъ и Виленской жид Абрамко Израйлевъ из судные избы освобожены. ${ }^{60}$

There is interesting evidence witnessing legendary Jewish solidarity. In February 1657, on the request of the Jews of Lida powiat, the Jews of Vilnius applied to the court of the Muscovite palatine. They asked the authorities to investigate the murder at Lida of two Slonim Jews returning from Vilnius with three barrels of salt and money. The prime suspect to the case the new citizen of Vilnius Mikolai Tiborskii proved his innocence with the help of witnesses. and the complaining Vilnius Jews wrote a petition to the effect: Милосердный Государь Царь и Великий князь Алексей Михайловичь всея Великия и Малья и Белья России Самодержеи

${ }^{59}$ ОР РНБ, ф. 550, д. F.II.85, fos. 151-152, 142-143v, 155-156.

${ }^{60}$ OР РНБ, ф. 550, д. F.II.85, fos. 150v-151, 136-136v, 152v-153. 
пожалуй нас сирот своих жидов вели Государь яво Микулая из судные избы освободит и челобития наме записать Царь Государь смилуйся пожалуй. ${ }^{61}$

The Vilnius Treasury recorded data about Jewish property; for instance a memorandum was issued to the Vilnius burgher Grigorii Gryzhevskii in April 1658 stating that the boat (витина, a boat for carrying grain), purchased by him in Vilnius from the treasury, belonged to the Jew Abram. ${ }^{62}$ Or a lawsuit of the early March 1658 in which Shakhovskii sent his investigating officer to the environs of the town Ostryn, Lida povet. The local gentry, peasants and Jews were questioned about the robbery committed by Russian soldiers, confrontations were organized, and the obtained data were taken to the court of the palatine. ${ }^{63}$

An even more interesting case was examined in March and April 1658. A young regiment drummer (elsewhere interpreter - толмач) Iurii Obramov (elsewhere - Abramka) was accused of attempted desertion and conversion to полским людем в каталики. It turned out that he was a Jew from Lublin, possibly converted to Orthodoxy, but since в роспросе у пытки повинился: говорил де я со пьянства и с молодости ть речи, что живу де у полуполковника, а бсть ньчево. И молвил, что хотел побыват(ь) у матки в Люблине, he was whipped and bailed. ${ }^{64}$

To sum up, it must be said that the chief cause of disaster for Lithuanian Jews in the middle of the seventeenth century was the aggression started by the Muscovite administration. Taking into account the contemporary state of Lithuanian Jews presented mainly by Vilnius materials it can be maintained that in the territory of Lithuania proper the Muscovite authorities treated Jews more leniently than they did in other conquered areas. Many documents

${ }^{61}$ ОР РНБ, ф. 550, д. F.II.85, fos. 154-154v, 147-148, 156-157.

62 ОР РГБ, ф. 178, оп. 4, nr. 6916(д. 193).

${ }^{63}$ ОР РГБ, ф. 178, оп. 4, nr. 6916(д. 164).

${ }^{64}$ ОР РГБ, ф. 178, оп. 4, nr. 6916(д. 165 и 166). А малой барабанщикъ 6 роспросе сказался: Юркою зовут, Обрамов, а родомъ бывал жидовин Люблина города. А взял де иво в Люблине полковникъ Володимер Фандикин. И как де полковника ево убили в прошлом году под Ригою и он де пристал к иляхтичу, $\kappa$ Бедницкому и служсил у нево, и был с нимъ на Москвь, и приьхал де с ним, шляхтичем, в Шклов и из Шклова де тот шляхтич ево от себя отпустил. И он де жил у полуполковника Кашпирова полку Яндера у Лаврентья Енуса. А как де пришли полки в Вилну, и ево де приписал полковникъ Кашпирь Яндер в барабанщики в девятую роту. 
show that 'our Sovereign the tsar loved and favoured' the Jews. In his attempts to win over as many strata of the population as possible, he flirted with all of them, including the Jews, trying to treat them on the same footing as the Christians of the occupied lands, at least in the framework of his justice administration. ${ }^{65}$ This state of affairs could suggest that the Muscovite administration simply had no special programme with regard to the Jews at least in the conquered western territories inhabited predominantly by the Catholics. However, the Jews, despite the rather hostile attitude of the local urban authorities towards them, retained their earlier old traditions of living together and their rather solid economic positions. Finally, in spite of a quite tough decision on the part of the Muscovite government to drive the Jews out of Vilnius, they nevertheless continued to live in the city. This state of affairs could possibly be accounted for either by the corruptibility of the local occupation authorities or by the indetermination of the central authorities with regard to these problems. Answers to these questions should probably be sought in the Moscow repositories of historical sources and in a more thorough analysis of the presented data.

Translated by Alfoncas Laučka

Author Details

Dr Elmantas Meilus is a member of the Department of Urban Research of the Lithuanian Institute of History. His sphere of scholarly interests is the history of Lithuanian cities and towns in the 17th and 18th centuries.

Address: Department of Urban Research, Lithuanian Institute of History, Kražiu 5, LT-01108 Vilnius

Email: meilus@istorija.1t

${ }^{65}$ In this respect analogous statements were made by Pendzich, Los żydów..., p. 160 (Można powiedzieć, że lata wojny paradoksalnie złagodzity postawę Moskwy wobec Żydów - musiała ona zaakceptować traktowanie ich tak, jak innych grup ludności, i nie mogła po prostu zarzqdzać zbiorowego ich palenia lub topienia), and they also coincide with the main conclusions of Shpirt's thesis, cf. А.М. Шпирт, Этноконфессиональные отношения, pp. 26-27 (10. Евреи, как и остальное население Великого княжества Литовского, серьезно пострадали от действий московских войск, многие из них были подвергнуты насильственному крещению. Вместе с тем характеризовать отношение русских властей к евреям как исключительно враждебное было бы преувеличением. Так, евреи прожсивали не только на захваченных западных землях Великого княжества Литовского, но и к востоку от Березины, т. е. на тех территориях, на которых московские власти официально разрешали жить лишь православным жителям Речи Посполитой.). 
LIETUVOS ŽYDAI MASKVOS OKUPACIJOS METU (1655-1660 M.)

Santrauka

\section{ELMANTAS MEILUS}

1654 m. Maskvos valstybės pradèta agresija prieš bendrą Lenkijos ir Lietuvos valstybę buvo pagrindinè priežastis nelaimių, ištikusių tuo metu Lietuvos Didžiosios Kunigaikštystės žydus. Remiantis išlikusiais duomenimis (daugiausia liečiančiais Vilnių), galima konstatuoti, kad Maskvos valdžia okupuotose vakarinėse LDK žemėse žydus traktavo daug švelniau, nei rytinèse srityse, apgyvendintose daugiausia stačiatikių. Stengdamiesi į savo pusę patraukti kuo platesnius okupuotų kraštų gyventojų sluoksnius, taip pat ir žydus, maskvėnai bent jau Lietuvoje, kur igyvedino savo teisètvarką, žydus teisè vienodai kaip ir krikščionis. Tai gali liudyti, kad Maskvos valdžia neturèjo tikslios programos (bent jau vakarinèje LDK dalyje, apgyvendintoje daugiausia kataliku), kaip elgtis žydų atžvilgiu. Tuo tarpu žydai, nors vietos gyventojai buvo gana priešiškai nusiteikę jų atžvilgiu (tai liudija ir to meto Vilniaus miesto valdžios carui skirtas prašymas iškeldinti žydus iš miesto), sugebejo surasti būdą, kaip sugyventi ir su vietiniais, ir su okupantų valdžia. Nors pats caras nurodè pašalinti žydus iš Vilniaus, kaip rodo šaltiniai, jie ir toliau gyveno šiame mieste. Tai gali liudyti tiek vietinès okupacinès valdžios paperkamuma, tiek centrinès valdžios neryžtingumą. Norint tai išsiaiškinti, reikia nuodugnesnių Rusijos archyvų tyrinejjimų. 